\title{
INVESTIGATING THE MODERATING EFFECT OF MARKETING CAPABILITY ON THE RELATIONSHIP BETWEEN CORPORATE SOCIAL RESPONSIBILITY (CSR) PRACTICE AND CORPORATE REPUTATION IN SMALL MEDIUM ENTERPRISES FOOD OPERATORS
}

\author{
Mohd Aidil Riduan Awang Kader* \\ Faculty of Business and Management, Universiti Teknologi MARA Pahang, Jengka Campus \\ Suhana Mohezar \\ Faculty of Business and Economics, University of Malaya \\ Nor Khairunnisa Mat Yunus \\ Faculty of Business and Management, Universiti Teknologi MARA Pahang, Raub Campus \\ Roslina Ali \\ Faculty of Business and Management, Universiti Teknologi MARA Pahang, Raub Campus \\ Mohamad Nazri \\ Faculty of Business and Economics, University of Malaya
}

\begin{abstract}
This study expanded on the existing research on corporate social responsibility (CSR) in food supply chains by investigating the moderating effect of marketing capability on the relationship between CSR practice and corporate reputation in the context of Malaysian small medium enterprises (SMEs). Data were collected from 264 SMEs operating in the Malaysian food supply chain using a questionnaire and analysed using Partial Least Square (PLS). The objectives of this study are as follows: 1) to investigate the awareness of CSR and the trends among local food SMEs, 2) to analyse the factors that motivate SMEs to implement CSR, and 3) to examine the moderating effect of marketing capability on the relationship between CSR practice and corporate reputation. This study found that supply chain partners' pressure and government support were the antecedent factors for CSR practice. In addition, this study also highlighted that CSR practice enhances the responding firms' corporate reputation. However, this study did not find substantial evidence to support the moderating role of marketing capability. The implication of this study implies that food operators should respond to the rising importance of CSR practice due to their powerful influence on a company's reputation. They should enter a collaborative relationship with their supply chain partners to gain access to resources needed for CSR implementation.
\end{abstract}

Keywords: Corporate Reputation; Corporate Social Responsibility; Food Supply Chain; Marketing Capabilities.

\footnotetext{
- Corresponding author: Faculty of Business and Management, Universiti Teknologi MARA Pahang, Jengka Campus, 26400, Bandar Pusat Jengka Pahang, Malaysia; Email: aidilriduan@uitm.edu.my
} 


\section{INTRODUCTION}

Corporate social responsibility (CSR) in the context of global supply chain and SMEs has been exhaustively discussed in various literature (de Vass Gunawardena et al., 2018; Khosroshahi et al., 2019; Souza-Monteiro \& Hooker, 2017; Wei et al., 2018). The rapid revolution of communication technologies, specifically the rise of social media, such as Facebook, Twitter, and Instagram, has further facilitated the widespread of information on food supply chain issues, such as animal welfare practices, food safety, genetically modified food, sustainable farming practices, and fair trade (Rutsaert et al., 2013). However, this process can be enhanced by increasing the marketing capabilities of the company. In this age of social media, the dissemination of opinion leaders' voices triggers a large scale of messages, which are communicated to the public globally. Notwithstanding the increased sensitivity of consumers, various stakeholders including shareholders, non-governmental (NGOs), public authorities, and trade unions, are gradually requesting firms to consider the social and environmental consequences of their business processes as part of their sustainability strategy (Zhang et al., 2015). Starbucks, for instance, was urged by the NGOs to provide better fair-trade prices to the coffee suppliers (Snider et al., 2017). Hence, it is not surprising that CSR has emerged as one of the top priorities for businesses.

CSR practice has long received considerable attention in the food and agriculture research arena. This is due to the fact that food and agricultural commodities are characterised as perishable goods, which may lose their quality whilst being transported and delivered through the downstream chains. Thus, responsible practices are needed to ensure that the quality of foods is maintained, so that food safety issues, such as Listeria, Salmonella, E. coli, and nitrogen, could be avoided (Soosay et al., 2012). The escalating developments in food technology, such as irradiation and genetic modification, are also viewed as the cause of great consumer awareness of CSR issues. Despite this, empirical studies on the CSR practice of food companies involving SMEs are still scarce. SMEs are commonly interpreted as the backbone of a country's economy as a result of their ability to innovate new products and processes (Xie et al., 2013). As such, many scholars (Bae \& Park, 2016; Bai et al., 2019; Chon, 2016; Sabki et al., 2019) highlighted the importance of small business engagements in CSR practice. Failure to do so may lead to incapability towards sustaining competitive advantage and being excluded from the global supply chains.

Marketing capability refers to integrative processes, in which a firm utilises its tangible and intangible resources to understand the complex consumers' needs and achieve superior brand recognition (Rahman et al., 2017). The moderating effect of marketing capability is important in the food supply chain to enhance corporate reputation, company competitiveness, and customer perception. Song et al. (2007) found that marketing capabilities allow firms to form a good relationship with customers and enhance the corporate reputation of the firms.

Within the context of the Malaysian industry, the competitiveness of local SMEs may depend on their ability to integrate CSR as part of their agenda. SMEs are the largest business entity in Malaysia, which contributes to RM 521.7 billion of Gross Domestic Product (GDP). The growth 
momentum was driven by the wholesale and retail trade, food and beverage, and the accommodation of the sub-sectors, which grew by 8.6\% in 2018 (SME Corp. Malaysia, 2018). While globalisation creates opportunities for increased manufacturing product exports, the integration of Malaysia into international markets entails the local food firms to achieve sustainable manufacturing practice by incorporating social and environmental dimensions, which may impede their participation (Mustafa, 2016). Given the importance of CSR implementation among SMEs, there is a need for a study to show how CSR affects the corporate reputation of the companies. Therefore, this study aims to investigate the awareness of CSR among local food SMEs and further attempts to analyse the factors that motivate SMEs to implement CSR, as well as its impact on corporate reputation. Furthermore, this study seeks to examine the moderating effect of marketing capability on the relationship between CSR practice and corporate reputation in the context of Malaysian SMEs.

\section{LITERATURE REVIEW AND HYPOTHESIS DEVELOPMENT}

\subsection{Corporate Reputation}

Corporate reputation could be referred to as a reflection of the degree to which the public is satisfied that the firms meet their expectations with products and services (Brammer \& Pavelin, 2016). Having a good corporate reputation is vital for business sustainability. It facilitates a firm to have a positive brand image to the public, including investors and bankers, especially in decreasing financial risks (Torugsa et al., 2012). New and emerging issues in the market have called upon firms to focus on building their reputation to enhance their credibility and image (de Vass Gunawardena et al., 2018; Kwon \& Lee, 2019; Park, 2019). Souza-Monteiro et al. (2017) demonstrated that CSR strategies are pertinent in ensuring company goodwill and reputation in the UK retail industry. Similarly, Gagalyuk (2017) illustrated that CSR transparency can be utilised as a tool to enhance the corporate reputation of agricultural firms in Ukraine. In Taiwan, CSR practice appears to help fast-food restaurants in building a good image and corporate reputation. CSR has been evidenced as being related to corporate reputation. The contributions of companies to social welfare are positively linked with corporate reputation (den Hond et al., 2014). Indeed, some firms that have bad reputations due to serious environmental, health, and safety-related accidents, have tried to change these perceptions by promoting good CSR practices. In the food sector specifically, corporate reputation plays a vital role as it indicates that the firm is reliable, honest, and will produce higher quality products.

\subsection{CSR Practice and Food Supply Chains}

CSR practice included activities that aim at minimising environmental impacts, such as food safety, green design, resource-saving, harmful material reduction, and recycling or reusing products throughout its entire life cycle, starting from food production until retaining earnings obtained by the firm, which are contributed back to society for benefits and upgrading infrastructures (Jamali, 2008). CSR generally discusses the actions pursued by organisations voluntarily and beyond their legal duties concerning their employees, communities, and the environment. It is a concept whereby firms achieve commercial success in ways that honour ethical values and respect people, communities, and the natural environment (de Hooge et al., 2018; Khosroshahi et al., 2019; Kong, 2012; Wei et al., 2018). Since food supply chains have unique characteristics, implementing CSR 
along the network may be deemed important and create challenges for the firm. Perishable foods, such as meat, seafood, vegetables, and fresh products, may lose their quality while progressing downstream in the supply chain, introducing challenges in maintaining quality as well as the freshness of the goods despite having long-distance travelling, different standards, and the involvement of various companies. Failure to maintain the quality from the source to the end consumers could lead to food safety issues, such as Listeria, Salmonella, E.coli, and nitrogen (Soosay et al., 2012).

The increasing demands of consumers in certain ways of producing food, both at farm and processing levels as well as the perishability of food products, escalate the complexity of the industry's supply chain management; thus, requiring more responsibility from all parties to maintain the quality and safety of food products. Cheung et al. (2015) argued that in the era of globalisation, irresponsible supplier practices put pressure on multinational corporations to protect their brands by adopting responsibility for assessing and controlling the practices of their suppliers. For instance, a German chicken producer had suffered a loss of brand image due to a violation of animal welfare standards, though the failures occurred on the supplier's side (Hartmann et al., 2013). In Malaysia, there are several irresponsible practices on the food supply chain where there is an increasing number of halal logo misuse cases and halal food's questionable status. Any improper description and inappropriate preparation of halal food have significant impacts on the demand for halal food and buyers' trust (Kamisah et al., 2018). Furthermore, Ruslan et al. (2018) reported that Muslim consumers in Malaysia had taken seriously food fraud scandal issues that involved the food supply chain, such as detection of pork DNA in chicken sausages, not following halal practices in the slaughtering process, and detection of porcine DNA in commercial candy products. In addition, the inability of the local vegetable suppliers to work with a foreign-owned hypermarket chain has resulted in them being excluded from the food supply network (Arshad, 2012). Drawing upon the literature mentioned above, this study postulates that:

\section{H1: CSR practice in the food supply chain is positively related to a firm's corporate reputation.}

\subsection{Government Support}

Enterprises' CSR and government policy development are interactive. Through the establishment of regulations and laws to regulate and adjust the behaviors of enterprises, the government plays a directing role in promoting the implementation of CSR. According to Lee (2008), the government also supported coordinating, increasing funds, popularising knowledge, and providing information and technical assistance for CSR programs to SME firms in the direction of developing and strengthening local SMEs. Many past studies have argued that organisations' decisions to adopt any ideas are not primarily based on efficiency goals, but are also influenced by the institutional environment, in which the firm is embedded (Budiarto et al., 2018; de Vass Gunawardena et al., 2018; Liu et al., 2019; Yin \& Zhang 2012; Zhao et al., 2014). This environment might include government agencies. Some scholars highlighted government support in a form of economic incentives as part of the institutional environment factors that would influence firms to embrace any innovation or idea, particularly for small-scale businesses since they are lacking in resources. For instance, Chon (2016) illustrated that Korean firms need financial support from the government to pursue CSR implementation effectively. 
Rahim et al. (2016) revealed that government support in the form of tax relaxation provided support among local halal food firms to improve their CSR practice. Apart from that, public sector regulatory and enforcement capacity plays an important role in underpinning CSR. Minimum environmental and social standards established raise concerns about firms being socially responsible. Failure to do so may result in them being excluded from the supply chain. In the food sector specifically, the industry is heavily regulated as it concerns public safety, health, and the environment (Pang et al., 2017). The introduction of the "General Food Law", which places responsibilities on producers, manufacturers, and the other food operators in the supply chain to ensure food safety, for instance, may compel firms to invest in CSR to maintain the integrity of agricultural commodities and food products. Governments may also encourage proactive responsibility practices by only allocating government contracts to firms that undertake a certain level of CSR investment. Hence, this study postulates that:

H2: Government support is positively related to CSR practice in the food supply chain.

\subsection{Supply Chain Partners Pressure}

Today, most organisations, including SMEs, recognise the importance of implementing a supply chain in their firms. Many supply chain partners had shown concern and interest towards CSR projects in terms of selections of suppliers besides providing training, education, and technical assistance related to CSR practice (Lee, 2008). Several studies maintain that the key to a firm's survival is through the acquisition and maintenance of resources (Harness et al., 2018; Kumar \& Rahman, 2016; Sancha et al., 2016; Zhu \& Lai, 2019). Often firms that hold market power and control over key resources needed in the supply chains, of which they are part of, exploit their power-dependence relationships and ensure that the partners comply with social and environmental standards. This is reflected in the agricultural and food industries of developing countries, in which local small-scale producers are pressured to comply with stricter food safety and quality requirements laid down by major supermarket chains to sustain their positions in the high-value markets (Esfahbodi et al., 2017).

Various supply chain partners involved in food production processes, such as multinational corporations (MNCs), large retailers, suppliers, third-party logistics and intermediaries, may have different quality and standards, which leads to conflicts in CSR exercise (Schnittfeld \& Busch, 2016). Given their market power, these supply chain partners play a significant role in determining what, how, and who should it be produced. They may also offer economic and technical support to enable their suppliers to achieve the required performance. Such firms, therefore, experience pressures to adopt the responsible practice to streamline with their supply chain partners for their business survival. Based on these arguments, this study postulates that:

\section{H3: Supply chain partners' pressure is positively related to CSR practice in the food supply chain.}

\subsection{Marketing Capability}

Marketing capabilities represent a complex set of abilities to perform a firm's operations efficiently and systematically using a series of the firm's synchronised resources. Fostering and distributing information amongst human resources to make better use of available resources is the basis of a 
firm's capabilities. According to Vorhies and Morgan (2005), marketing capabilities are apparent when the individual has an excellent quality of customer service, effective promotional activities, good market research effort, and the ability to introduce new products to market rapidly concerning their competitors. Many previous studies suggested that the marketing capability of CSR activities may have a direct effect on consumers' purchase intentions and firms' performance (Hirunyawipada \& Xiong, 2018; Pomering, 2017; Sardianou et al., 2017). While differentiation strategy through CSR practice could facilitate firms in sustaining their competitive advantage, they may not be able to reap the economic returns if the potential customers are not fully aware of CSR characteristics embedded in the products purchased. These characteristics may not be evident to customers at first glance, tendering businesses to have a good marketing capability to raise awareness of individuals interested in purchasing such products.

As opposed to furniture and clothing that allow customers to establish the quality of the goods before purchasing, food is considered as experience goods, in which the true value of the products could only be determined after consumption. Hence, such goods require a good marketing mix to provide more information and tie the product to an established brand. Marketing capability contributes to increasing corporate reputation and therefore, company competitiveness and customer perception about a company's CSR practices can boost this relationship. Whilst previous studies suggest that CSR practices lead to corporate reputation (den Hond et al., 2014; Gagalyuk, 2017), this relationship may not be linear. On the one hand, food companies may not be able to enhance their reputation through CSR practice if the customers are not aware of these exercises. On the other hand, customers are found to be willingly spending more money and are more loyal to businesses that have showcased that they prioritise CSR practice. Following these arguments, this study proposes that:

\section{H4: Marketing capability moderates the relationship between CSR practice and corporate reputation}

Following the extant literature, a research framework is developed. The framework posits that CSR practice has a positive influence on a firm's corporate reputation. Nevertheless, this relationship is expected to be strengthened with the marketing capabilities. In addition, CSR practice is expected to be affected by government support and supply chain partners' pressure (Figure 1).

Figure 1: Conceptual Framework

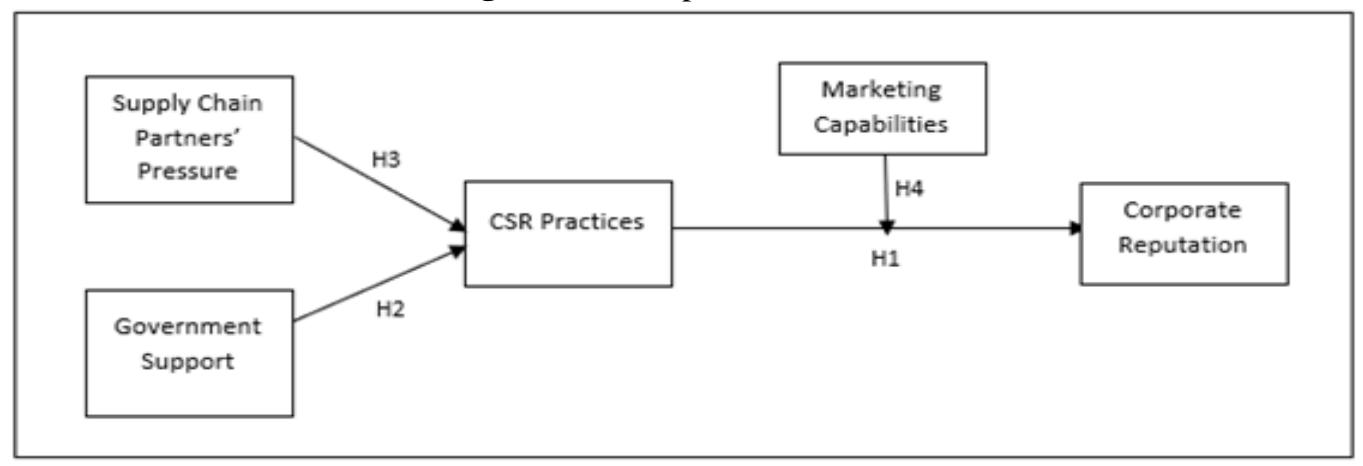




\section{METHODOLOGY}

This study employed a quantitative analysis approach where a survey method was used, using cross-sectional data. SPSS software was used to clean the data and analyse the descriptive statistics, while Partial Least Square (PLS) software was used to test the measurement model and finally, the structural model. This software can help to analyse construct validity causal relations among constructs in multistage models (Fornell \& Bookstrein, 1982). The population for this study is small and medium companies in food businesses. The list of the firms was obtained from Small and Medium Industries Development Corporation (SMIDEC).

The stratified random sampling was applied to obtain a representative number of manufacturing and service firms in Malaysia. Selected companies exhibit a wide range of sectors, and they were located in different parts of Malaysia to avoid biased selection. In the end, 264 companies were chosen to be included in the sample.

\subsection{Operationalisation of Constructs}

Table 1 presents the operationalisation of constructs. The measures used in this study were adapted from the previous literature. The independent variables: government support and supply chain partners' pressure, were adapted from Lee (2008) and measured using four and five items, respectively. In addition, the items for the CSR practice construct were measured using ten items adapted from Jamali (2008). Respondents were asked to indicate the level of their engagement and response towards social responsibility. Based on Torugsa et al. (2012), four items were adopted to assess the impact of exercising CSR on firms' corporate reputation. Respondents were asked to rate their perceptions on the level of their firm's performance in terms of corporate reputation in relation to CSR practice on a 5-point Likert scale, ranging from 1 (strongly disagree) to 5 (strongly agree). Marketing capability was assessed based on four items adapted from Vorhies and Morgan (2005).

Table 1: Operationalisation of Constructs

\begin{tabular}{lllc}
\hline \hline \multicolumn{1}{c}{ Variables } & & \multicolumn{1}{c}{ Items } & Source \\
\hline $\begin{array}{l}\text { Government } \\
\text { Support }\end{array}$ & GS1 & The government coordinates the CSR initiatives \\
& GS2 & $\begin{array}{l}\text { The government increases funds for CSR initiatives } \\
\text { The government has provided information and technical } \\
\text { assistance to small and medium-sized firms } \\
\text { The government has popularised knowledge of CSR practice }\end{array}$ & \\
& GS4 & Lee (2008) & \\
$\begin{array}{l}\text { Supply } \\
\text { Chain }\end{array}$ & SC1 & $\begin{array}{l}\text { Our supply chain partners incorporate CSR considerations in } \\
\text { selecting their supplies and suppliers }\end{array}$ & Lee (2008) \\
Pressure & SC2 & $\begin{array}{l}\text { Our supply chain partners request us to practice CSR } \\
\text { Our supply chain partners have interests in CSR practice } \\
\text { Our supply chain partners provide us with training, education } \\
\text { and technical assistance relating to CSR practice } \\
\text { Our supply chain partners have managers who have an interest }\end{array}$ & \\
& SC4 & in CSR initiatives & \\
\hline
\end{tabular}

CSR Practice $\quad$ CS1 We use naturally bred animals in our food production 


\begin{tabular}{|c|c|c|c|}
\hline \multirow[t]{10}{*}{ Variables } & & Items & Source \\
\hline & CS2 & $\begin{array}{l}\text { We use minimal food additives and processing aids in our food } \\
\text { production }\end{array}$ & \multirow[t]{9}{*}{$\begin{array}{l}\text { Jamali } \\
(2008)\end{array}$} \\
\hline & $\mathrm{CS} 3$ & Our products are healthy & \\
\hline & CS4 & Our products have complete declaration of content & \\
\hline & CS5 & $\begin{array}{l}\text { We educate own-self and upgrade our knowledge on food } \\
\text { safety }\end{array}$ & \\
\hline & CS6 & We incorporate environmental policy in our corporate goals & \\
\hline & CS7 & We use recyclable product packaging & \\
\hline & CS8 & $\begin{array}{l}\text { We use some portions of retained earnings to help local } \\
\text { community to consummate the public infrastructure }\end{array}$ & \\
\hline & CS9 & $\begin{array}{l}\text { We allocate some portions of retained earnings to charitable } \\
\text { organisations }\end{array}$ & \\
\hline & CS10 & $\begin{array}{l}\text { Our products are produced in settings of positive working } \\
\text { conditions and under good term of employment for all workers }\end{array}$ & \\
\hline \multirow[t]{4}{*}{$\begin{array}{l}\text { Corporate } \\
\text { Reputation }\end{array}$} & CR1 & $\begin{array}{l}\text { Socially responsible activities have improved our firm's brand } \\
\text { image }\end{array}$ & \multirow[t]{4}{*}{$\begin{array}{l}\text { Torugsa et } \\
\text { al. }(2012)\end{array}$} \\
\hline & $\mathrm{CR} 2$ & $\begin{array}{l}\text { Socially responsible activities have improved our firm's } \\
\text { standing with banks; and help to gain easy access to bank loans }\end{array}$ & \\
\hline & CR3 & $\begin{array}{l}\text { Socially responsible activities have improved our firm's } \\
\text { standing with investors and reduce financial risks }\end{array}$ & \\
\hline & CR4 & $\begin{array}{l}\text { Socially responsible activities have helped us to obtain } \\
\text { favourable public image }\end{array}$ & \\
\hline \multirow[t]{4}{*}{$\begin{array}{l}\text { Marketing } \\
\text { Capability }\end{array}$} & MC1 & $\begin{array}{l}\text { In relative to our competitors, our firm has an excellent quality } \\
\text { of customer service }\end{array}$ & \multirow{4}{*}{$\begin{array}{l}\text { Vorhies \& } \\
\text { Morgan } \\
(2005) .\end{array}$} \\
\hline & MC2 & $\begin{array}{l}\text { In relative to our competitors, our firm has effective } \\
\text { promotional activities }\end{array}$ & \\
\hline & $\mathrm{MC} 3$ & $\begin{array}{l}\text { In relative to our competitors, our firm has a good market } \\
\text { research effort }\end{array}$ & \\
\hline & MC4 & $\begin{array}{l}\text { In relative to our competitors, our firm has an ability to } \\
\text { introduce new products to market rapidly }\end{array}$ & \\
\hline
\end{tabular}

\subsection{Survey Administration and Sample}

A survey method by using a questionnaire was adopted in this study to test the conceptual model and hypotheses developed. The questionnaire was pilot-tested with a sample of twenty-seven small and medium-scale food manufacturers. Feedback from the pilot test was used to refine the questions for the larger study. The sampling frame for this study was drawn from the list of food manufacturers registered with the Small and Medium Industries Development Corporation (SMIDEC). A questionnaire, including a cover letter, self-addressed, and stamped envelopes were mailed to the CEO, managers, or owners whose roles are crucial in developing responsible business practices. Out of 1,200 questionnaires mailed out, 264 questionnaires were returned, which resulted in a 22 per cent response rate. Table 2 presents the sample characteristics. The results reflected that most of the samples have less than 5 full-time employees, indicating that they are micro-sized firms. The majority of them are manufacturers and retailers. 
Table 2: Sample Characteristics

\begin{tabular}{llll}
\hline \hline & & Frequency & Percentage (\%) \\
\hline Number of employees & $<5$ & 121 & 45.8 \\
& $5-50$ & 94 & 35.6 \\
& $51-100$ & 27 & 10.2 \\
& $101-150$ & 10 & 3.8 \\
& $>151$ & 12 & 4.5 \\
\hline Position in the chain & Input suppliers & 56 & 21 \\
& Manufacturers & 61 & 23 \\
& Wholesalers/agents/importers & 42 & 15.9 \\
& Retailers & 64 & 24.2 \\
& Packaging & 26 & 9.8 \\
& Logistics and Transportation & 15 & 6.8 \\
\hline \hline
\end{tabular}

The first objective of this study is to investigate the awareness of CSR practice among local food SMEs. Table 3 presents the awareness of the respondents of CSR practice. More than half (60.3\%) of the food operators studied agreed that this exercise has formed part of their organisation's cultural norms and is important to their firms. This finding indicated that many local food companies have built awareness of what CSR is and recognise the importance of such practice. These perceptions are contradictory with the findings reported by Welford and Frost (2006), in which they found that many companies tend to see the CSR practice as a nuisance and consider it as no more than an instrument of compliance. Perhaps, perceived failures, globalisation impact, and the revolution of communication technologies, which have facilitated the widespread of information, could explain its rising relevance.

Table 3: Awareness on CSR Practice

\begin{tabular}{lcccccc}
\hline \hline & \multicolumn{2}{c}{$\begin{array}{c}\text { CSR is part of our cultures } \\
\text { norms }\end{array}$} & \multicolumn{2}{c}{$\begin{array}{c}\text { CSR is part of our } \\
\text { company's value }\end{array}$} & \multicolumn{2}{c}{$\begin{array}{c}\text { CSR is strategically } \\
\text { important }\end{array}$} \\
\cline { 2 - 7 } & Frequency & Percent & Frequency & Percent & Frequency & Percent \\
\hline Strongly disagree & 11 & 4.2 & 11 & 4.2 & 13 & 4.9 \\
Disagree & 20 & 7.6 & 8 & 3.0 & 15 & 5.7 \\
Neutral & 74 & 28.0 & 89 & 33.7 & 86 & 32.6 \\
Agree & 101 & 38.3 & 59 & 22.3 & 60 & 22.7 \\
Strongly Agree & 58 & 22.0 & 97 & 36.7 & 90 & 34.1 \\
\hline Total & 264 & 100.0 & 264 & 100.0 & 264 & 100.0 \\
\hline \hline
\end{tabular}

\section{RESULTS AND DISCUSSION}

\subsection{Measurement Model}

A measurement model comprising all the construct of interests was evaluated. Convergent and A measurement model comprising all the constructs of interest was evaluated. Convergent and discriminant validity tests were conducted to ensure that the measurements were in agreement and did not reflect other variables (Hair et al., 2013). Convergent validity was examined based on factor loadings, composite reliability, and average variance extracted (AVE). As indicated in Table 4, all the variables had composite reliability and AVE greater than the cut-off point of 0.7 and 0.5 , 
respectively (Hair et al., 2013). Three items measuring CSR practice were dropped due to the low factor loadings (Bagozzi \& Yi, 1988). These results demonstrated the convergent validity of the measures used. In this study, discriminant validity was tested based on the Fornell and Larcker (1981) approach. All the scales appeared to have a substantially higher AVE value compared to their correlation with other constructs, providing evidence of discriminant validity (Table 5). Table 6 exhibited the summary of reliability analysis. The results showed that the Cronbach alpha values for all measured variables were all above 0.7 as recommended by Nunnally (1978). This indicated that measured variables have adequate internal consistency reliability. The results of the measurement model indicated that various validity and reliability criteria were satisfied. Therefore, constructs developed in this measurement model could be used to test the structural model and the associated hypotheses.

Table 4: Convergent Validity

\begin{tabular}{|c|c|c|c|c|c|}
\hline Variables & Items & $\begin{array}{c}\text { Factor } \\
\text { Loading }\end{array}$ & T-value & $\begin{array}{c}\text { Average } \\
\text { Variance } \\
\text { Extracted }\end{array}$ & $\begin{array}{l}\text { Composite } \\
\text { Reliability }\end{array}$ \\
\hline \multirow{4}{*}{$\begin{array}{l}\text { Corporate } \\
\text { Reputation }\end{array}$} & CR1 & 0.796 *** & 16.863 & \multirow{4}{*}{0.563} & \multirow{4}{*}{0.836} \\
\hline & CR2 & $0.766 * * *$ & 17.377 & & \\
\hline & CR3 & $0.719 * * *$ & 12.783 & & \\
\hline & CR4 & $0.71 * * *$ & 13.266 & & \\
\hline \multirow{4}{*}{$\begin{array}{l}\text { Government } \\
\text { Support }\end{array}$} & GS1 & $0.798 * * *$ & 30.679 & \multirow{4}{*}{0.69} & \multirow{4}{*}{0.899} \\
\hline & GS2 & $0.837 * * *$ & 37.761 & & \\
\hline & GS3 & $0.843 * * *$ & 36.558 & & \\
\hline & GS4 & $0.842 * * *$ & 43.932 & & \\
\hline \multirow{5}{*}{$\begin{array}{l}\text { Supply Chain } \\
\text { Partner } \\
\text { Pressure }\end{array}$} & SC1 & $0.79 * * *$ & 28.054 & \multirow{5}{*}{0.565} & \multirow{5}{*}{0.86} \\
\hline & $\mathrm{SC} 2$ & $0.803 * * *$ & 31.304 & & \\
\hline & SC3 & $0.527 * * *$ & 1.805 & & \\
\hline & $\mathrm{SC} 4$ & $0.793 * * *$ & 29.96 & & \\
\hline & SC5 & $0.774 * * *$ & 27.629 & & \\
\hline \multirow{7}{*}{$\begin{array}{l}\text { Corporate } \\
\text { Social } \\
\text { Responsibility }\end{array}$} & $\mathrm{CS} 2$ & $0.639 * * *$ & 13.97 & \multirow{7}{*}{0.513} & \multirow{7}{*}{0.88} \\
\hline & CS4 & $0.695 * * *$ & 19.436 & & \\
\hline & CS6 & $0.745^{* * *}$ & 23.961 & & \\
\hline & CS7 & $0.755 * * *$ & 28.112 & & \\
\hline & CS8 & $0.736 * * *$ & 22.434 & & \\
\hline & CS9 & $0.734 * * *$ & 21.917 & & \\
\hline & CS10 & $0.696 * * *$ & 19.752 & & \\
\hline \multirow{4}{*}{$\begin{array}{l}\text { Marketing } \\
\text { Capability }\end{array}$} & MC1 & $0.698 * * *$ & 12.255 & \multirow{4}{*}{0.541} & \multirow{4}{*}{0.825} \\
\hline & $\mathrm{MC} 2$ & $0.711 * * *$ & 16.155 & & \\
\hline & MC3 & $0.733 * * *$ & 15.343 & & \\
\hline & MC4 & $0.797 * * *$ & 24.765 & & \\
\hline
\end{tabular}

Note: CS1, CS3 and CS5 were dropped due to the low factor loading, $* * * p<0.001$ 
Table 5: Discriminant Validity

\begin{tabular}{llllllll}
\hline \hline & Mean & SD & CR & GS & SP & CS & MC \\
\hline Corporate reputation (CR) & 4.71 & 0.89 & $\mathbf{0 . 7 5}$ & & & & \\
Government support (GS) & 3.09 & 0.40 & 0.23 & $\mathbf{0 . 8 3}$ & & & \\
Supply Chain Partner Pressure (SC) & 4.58 & 0.14 & 0.59 & 0.11 & $\mathbf{0 . 7 5}$ & & \\
Corporate Social Responsibility (CS) & 3.44 & 0.88 & 0.22 & 0.41 & 0.55 & $\mathbf{0 . 7 1}$ & \\
Marketing Capability (MC) & 4.25 & 0.66 & 0.42 & 0.27 & 0.19 & 0.29 & $\mathbf{0 . 7 3}$ \\
\hline \hline
\end{tabular}

Table 6: Summary of Reliability Analysis

\begin{tabular}{lcc}
\hline \hline Variables & Cronbach's Alpha & N of item \\
\hline Corporate reputation (CR) & 0.763 & 4 \\
Government support (GS) & 0.851 & 4 \\
Supply Chain Partner Pressure (SC) & 0.768 & 5 \\
Corporate Social Responsibility (CS) & 0.865 & 7 \\
Marketing Capability (MC) & 0.728 & 4 \\
\hline \hline
\end{tabular}

\subsection{Structural Model}

Assuming that the measurement model satisfied the psychometric assessment, a structural model was constructed based on the results of the measurement model. Nonparametric bootstrapping was applied (Wetzels et al., 2009) with 2,000 replications to test the structural model. The predictive accuracy of the model was evaluated in terms of the portion of the variance explained. The results suggested that the model is capable of explaining $26 \%$ of the variance in corporate reputation and $40 \%$ of the variance in CSR. As suggested by Chin et al. (2003), a hierarchical approach was employed to test the hypotheses, in which the authors first estimated a model with the main effects (and covariates) only, and then added the interaction effects. The results indicated that the effects of government support $(\beta=0.20, p<0.01)$ and supply chain partners pressure $(\beta=0.49, p<0.01)$ on CSR are significant and positive (Table 7). As such, $\mathrm{H} 2$ and $\mathrm{H} 3$ are supported. This study also found that CSR is significantly related to corporate reputation $(\beta=0.37, p<0.01)$, supporting H1.

Table 7: Structural Model Analysis

\begin{tabular}{clccc}
\hline \hline Hypotheses & \multicolumn{1}{c}{ Relationship } & $\begin{array}{c}\text { Path } \\
\text { Coefficient }\end{array}$ & $\begin{array}{c}\text { T-value } \\
\text { Direct effect }\end{array}$ & $\begin{array}{c}\text { Decisio } \\
\text { n }\end{array}$ \\
\hline $\mathrm{H}_{1}$ & $\begin{array}{l}\text { Corporate social responsibility -> corporate } \\
\text { reputation }\end{array}$ & 0.37 & $6.29 * * *$ & $\begin{array}{c}\text { Supporte } \\
\mathrm{d}\end{array}$ \\
$\mathrm{H}_{2}$ & $\begin{array}{l}\text { Government support -> corporate social } \\
\text { responsibility }\end{array}$ & 0.20 & $3.16^{* * * *}$ & $\begin{array}{c}\text { Supporte } \\
\text { d }\end{array}$ \\
$\mathrm{H}_{3}$ & $\begin{array}{l}\text { Supply chain partners pressure -> corporate } \\
\text { social responsibility }\end{array}$ & 0.49 & $9.17 * * *$ & $\begin{array}{c}\text { Supporte } \\
\mathrm{d}\end{array}$ \\
\hline \hline
\end{tabular}

With regard to the moderating hypotheses, the multi-group analysis was performed, in which the respondents were divided into two groups: high and low marketing capability (MC). The distinction was based on the median split of the construct scores (4.25). The high MC group ( $\mathrm{n}=$ 156) has a mean level of 4.27 and a standard deviation of 0.29 , whereas the low MC group ( $\mathrm{n}=$ 
108) has a mean level of 3.58 and a standard deviation of 0.52 . The authors present the moderating effect of MC in Table 8. The multigroup analysis equation was used as suggested by Chin et al. (2003) to examine the interaction effect.

$$
t_{i j}=\frac{P_{1}-P_{2}}{\frac{\sqrt{n_{1}-1 \times S E_{2}^{1}+\left(n_{2}-1\right) \times S E_{2}^{2}}}{n_{1}+n_{2}-2}}
$$

where

$p i=$ path coefficient in the structural model of $M C i$

$n i=$ sample size of the data set for $M C i$

$S E i=$ standard error of path in the structural model for $M C i$

$t i j=t$-statistic with $n 1+n 2$; two degrees of freedom

$i=1$ for the high-MC group and $j=2$ for the low-MC group

Table 8: Moderating Effect

\begin{tabular}{cccccc}
\hline \hline Hypotheses & Relationship & \multicolumn{2}{c}{ Path Coefficient } & \multicolumn{1}{c}{ T- } & Decision \\
\cline { 3 - 4 } & Value & \\
\hline $\mathrm{H}_{4}$ & $\begin{array}{c}\text { CSR practice ---> } \\
\text { Corporate reputation }\end{array}$ & 0.29 & Low MC & & Value \\
\hline \hline
\end{tabular}

The results shown in Figure 2 indicate that the coefficients of the path between CSR and corporate reputation for the high and low MC groups are not significantly different $(\mathrm{p}=0.964)$ from their coefficients in the structural model.

Figure 2: Comparison of the Path Coefficient between the High and Low MC Groups

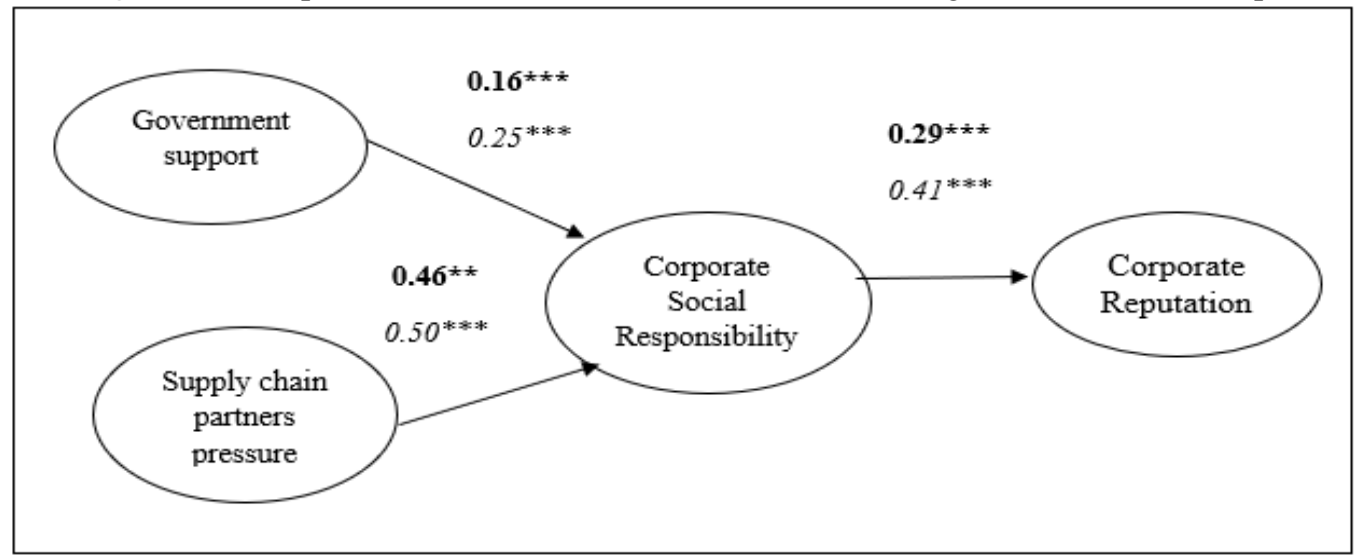

Note: Bold figures indicate the high-MC group, and italics indicate the low-MC group. ***P<.001.

This study attempted to determine the awareness of CSR among local food SMEs and to investigate the factors that influence food businesses to practice CSR, as well as the impact of such practice on corporate reputation. This research extended prior empirical works by focusing specifically on 
small businesses. This study found that both government support and supply chain partners' pressure play a role in influencing firms to undertake good CSR practices.

The government's involvement is associated with a greater willingness of small food operators to take part in CSR initiatives. This finding reconfirmed prior studies conducted by Budiarto et al. (2018), de Vass Gunawardena et al. (2018), Liu et al. (2019), and Pang et al. (2017). The governmental direct or indirect support in terms of financial assistance, for instance, is thought to be an external source of finance for these companies since they often face restrictions in any innovation activities due to the lack of internal funding. The government intervention in providing funding could provide the impetus for small businesses to attempt such an exercise. The result is not surprising, given that the markets in developing nations are characterised by information asymmetry, imperfections, a less supportive regulatory framework, and immature infrastructure. These factors perhaps make firms in this study regarding government support as pertinent in sustaining and fostering CSR practice.

In a similar vein, this study also demonstrated a clear influence of supply chain partners' pressure in CSR practice. This finding was in line with prior empirical works conducted by Esfahbodi et al. (2017), Harness et al. (2018), Schnittfeld and Busch (2016), and Zhu and Lai (2019). Pressure from supply chain partners, particularly the downstream customer, forces firms to conform and be perceived as more legitimate and trustworthy. Given that Malaysia exports a large percentage of its goods to other developed countries, such as the USA (Hsu et al., 2013), local manufacturers are bound to adopt business practices that serve the foreign countries' interests. Consumers in these countries have started to question the social and environmental effects of the goods that they buy and expect firms to choose suppliers that are conscious of social responsibility. With the high level of interdependency between local firms, multinational corporations, and foreign markets, businesses in this study may experience high pressure to adopt CSR practices.

Some studies have demonstrated that CSR practice leads to a firm's corporate reputation (Brammer \& Pavelin, 2016; Gagalyuk, 2017; de Vass Gunawardena et al., 2018; Kwon \& Lee, 2019; Park, 2019). The finding suggested that the responding firms realise the benefits of CSR practice in enhancing their corporate image. The results demonstrated that buyers' perceptions about suppliers' CSR activities may induce buyers' positive awareness and associations of suppliers' products. In today's highly competitive market environment, many firms have utilised CSR as a strategic means to respond to various stakeholders' expectations. CSR practices may create and foster buyers' beliefs that firms adhere to ethical standards and care about social wellbeing, which in turn could impact the corporate reputation positively. Buyers that become aware of the ethical implications of organisational behaviour perceive that the firm will maintain certain quality standards, leading to enhanced corporate reputation. Given that the firms studied are mainly SMEs that supply for overseas markets, they may see the importance of CSR practice as a means to gain corporate reputation. This is because buyers, especially from the developed countries, are more concerned about social and environmental issues, and request firms to consider these elements as part of their sustainable strategy (Samuel et al., 2011).

While few studies (Pomering, 2017; Sardianou et al., 2017) suggested that firms may not be able to reap the potentials of CSR if their customers are not fully aware of the CSR characteristics embedded in the products offered, this research, however, provided conflicting results. The reason behind this could be due to the consumers' psychological behaviour in this study, who are more interested in institutional CSR programs that attempt to satisfy moral obligations, rather than 
promotional CSR, which is targeted at selling products (Öberseder et al., 2011). Moreover, since the responding firms in this study are SMEs, they may not give priority to enhancing their marketing capability for corporate reputation. They may direct their limited resources and capabilities towards other activities for the short-term benefits of their shareholders and attempting to satisfy the daily demands of customers more (Valdez-Juárez et al., 2018). Apart from this, given that Malaysia is characterised as having a collectivist culture, in which social pressures play a pertinent role in influencing an individual's behaviour (Hofstede \& Bond, 1988), the finding was not surprising. As asserted by Narwal and Kant (2014), the way consumers perceive new products or companies may be driven by the need to attain social approval and recognition. Society members who have a positive experience with the product may disseminate positive feedback to their friends or family members in the social network, which would enhance the corporate reputation.

\section{CONCLUSION}

This study provided insight into the CSR practice among local SMEs in Malaysia. It specifically investigated the level of awareness of this practice, and determined the effect of supply chain partners' pressure and government support in determining the CSR practice among the firms studied. Additionally, this study also attempted to explain how the relationship between CSR practice and corporate reputation is moderated by marketing capability. The findings indicated that CSR practice is influenced by both supply chain partners' pressure and government support, and the practice enables the responding firms to enhance their corporate reputation. This study, however, did not have substantial evidence to establish the role of marketing capability as a moderated variable.

The findings of this study suggested that managers in the Malaysian food businesses start considering the strategic role of CSR in enhancing their corporate reputation. This is particularly important given the strong effect of rapid information technology. The proliferation of social media networks, such as Facebook, Instagram, and Twitter, has granted the public opportunities for unlimited access to information regarding any company's CSR behaviours and responses. For firms engaging in CSR exercise, the increased accessibility could potentially facilitate them in crafting and distributing positive information to a wide range of stakeholders, including endconsumers. They are suggested to be proactively involved and support CSR before any incident involving irresponsible behaviours are reported in the media, as this would lead to disastrous effects.

Although the increased scope of CSR practice could enhance corporate reputation, proactive collaborations with supply chain members are critical. A collaboration with supply chain members as an alternative to embracing CSR may facilitate the SMEs to gain access to the organisational knowledge or financial resources of larger counterparts, allowing them to create synergies. These steps would potentially benefit them since they are constrained by restricted resources and capabilities. On the Malaysian front, social and environmental awareness have brought pressure to the government, as the economy depends heavily on foreign direct investment. The Malaysian government actively supports CSR and this is reflected in the country's policy regulation and tax incentives. For instance, the government has also established regulations to prevent the use of hazardous or toxic elements in products and promote the use of recycled materials (Hsu et al., 2013). These regulations and support set as an important trigger for CSR practice in SMEs, 
specifically among food companies. Despite these various initiatives, it is possible that many SMEs in the industry are still unaware of or underutilising the resources provided. Hence, this creates an imperative need for more proactive information dissemination across the industry to promote and coordinate the CSR practice in the Malaysian economy.

Whilst this study could extend prior literature on CSR practice in food supply chains, the present research has some limitations. Firstly, as this study was conducted in Malaysia, there may be certain characteristics of Malaysian firms that might not apply to other countries, which raises the generalisation. Next, since the sampling frame was obtained from the Small and Medium Industries Development Corporation (SMIDEC) directory, which restricts the population to only food businesses that are registered with the agency, the results may be confounded to some degree of external validity. Lastly, since the study relied on cross-sectional data that measure the predictors and outcome at one point in time, this study may not effectively tap the full benefits of CSR on corporate reputation. Despite these limitations, it is believed that this study offered important implications for food supply chain research and CSR practice from the view of SMEs in a developing country, specifically Malaysia.

\section{REFERENCES}

Arshad, F. M. (2012). The New Supply Chain: Implications to the Fresh Fruits and Vegetables Sector in Malaysia. International Journal of Business and Social Research, 2(4), 255-81.

Bae, J. H., \& Park, H. S. (2016). The Effect of SME's Organizational Capabilities on Proactive CSR and Business Performance. Journal of Digital Convergence, 14(3), 181-197.

Bagozzi, R. P., \& Yi, Y. (1988). On the evaluation of structural equation models. Journal of the Academy of Marketing Science, 16(1), 74-94.

Bai, Y., Song S., Jiao J., \& Yang R. (2019). The impacts of government R\&D subsidies on green innovation: Evidence from Chinese energy-intensive firms. Journal of Cleaner Production, 233, 819-829.

Brammer, S. J., \& Pavelin, S. (2016). Corporate Reputation and Corporate Social Responsibility. In A. Guler \& D. Crowther, A Handbook of Corporate Governance and Social Responsibility (pp. 437-447). USA: Routledge.

Budiarto, D. S., Widya Sari, M., Sudaryana A., \& Prabowo M.A. (2018). IT Implementation on Indonesian SMEs: Challenge or Barriers? International Journal of Business and Society, 19(4), 546-553.

Cheung, Y. L., Kong, D., Tan, W., \& Wang, W. (2015). Being good when being international in an emerging economy: The case of China. Journal of Business Ethics, 130(4), 805-817.

Chin, W. W., Marcolin, B. L., \& Newsted, P. R. (2003). A partial least squares latent variable modeling approach for measuring interaction effects: Results from a Monte Carlo simulation study and an electronic-mail emotion/adoption study. Information systems research, 14(2), 189-217.

Chon, M. L. (2016). CSR and SME in Korean Market. Indian Journal of Science and Technology, 43(9), 1-7.

de Hooge, I. E., Dulm, I. V., Hans, C. M., \& Trijp, V. (2018). Cosmetic specifications in the food waste issue: Supply chain considerations and practices concerning suboptimal food products. Journal of Cleaner Production, 183, 698-709. 
de Vass Gunawardena, T., Masudin, I., \& Jie, F. (2018). Corporate social responsibility in supply chains: The impact in the context of global supply chains. International Journal of Business and Society, 19(3),678-698.

den Hond, F., Rehbein, K. A., Bakker, F. G., \& Lankveld, H. K. V. (2014). Playing on two chessboards: Reputation effects between corporate social responsibility (CSR) and corporate political activity (CPA). Journal of Management Studies, 51(5), 790-813.

Esfahbodi, A., Zhang, Y., Watson, G., \& Zhang, T. (2017). Governance pressures and performance outcomes of sustainable supply chain management- An empirical analysis of UK manufacturing industry. Journal of Cleaner Production, 155, 66-78.

Fornell, C. \& Bookstein, F.L. (1982). Two structural equation models: LISREL and PLS applied to consumer exit-voice theory. Journal of Marketing Research, 19(4), 440-452.

Fornell, C. \& Larcker, D.F. (1981). Evaluating structural equation models with unobservable and measurement error. Journal of Marketing Research, 18(1), 39-50.

Gagalyuk, T. (2017). Strategic role of corporate transparency: the case of Ukrainian agroholdings. International Food and Agribusiness Management Review, 20(2), 257-278.

Hair, J. F., Hult, G. T. M., Ringle, C. M., \& Sarstedt, M. (2013). A Primer on Partial Least Squares Structural Equation Modelling (PLS-SEM). Thousand Oaks: Sage Publications.

Harness, D., Ranaweera, C., Karjaluoto, H., \& Jayawardhena, C. (2018). The role of negative and positive forms of power in supporting CSR alignment and commitment between large firms and SMEs. Industrial Marketing Management, 75, 17-30.

Hartmann, M., Heinen, S., Melis, S., \& Simons, J. (2013). Consumers' awareness of CSR in the German pork industry. British Food Journal, 115(1), 124-141.

Hirunyawipada, T. \& Xiong, G. (2018). Corporate environmental commitment and financial performance: Moderating effects of marketing and operations capabilities. Journal of Business Research, 86, 22-31.

Hofstede, G. \& Bond, M. (1988). The Confucius connection from cultural roots to economic growth. Organizational Dynamics, 16, 4-21.

Hsu, C. C., Choon T. K., Hanim M. Z. S., \& Jayaraman, V. (2013). Supply chain drivers that foster the development of green initiatives in an emerging economy. International Journal of Operations \& Production Management, 33(6), 656-688.

Jamali, D. (2008). A stakeholder approach to corporate social responsibility: A fresh perspective into theory and practice. Journal of Business Ethics, 82(1), 213-231.

Kamisah, S., Mokhtar, A., \& Hafsah, A. (2018). Halal practices integrity and halal supply chain trust in Malaysian halal food supply chain. International Food Research Journal, 25(1), 5762.

Khosroshahi, H., Rasti-Barzoki, M., \& Hejazi, S. R. (2019). A game theoretic approach for pricing decisions considering CSR and a new consumer satisfaction index using transparencydependent demand in sustainable supply chains. Journal of Cleaner Production, 208, 1065 1080.

Kong, D. (2012). Does corporate social responsibility matter in the food industry? Evidence from a nature experiment in China. Food Policy, 37(3), 323-334.

Kumar, D., \& Rahman, Z. (2016). Buyer supplier relationship and supply chain sustainability: empirical study of Indian automobile industry. Journal of Cleaner Production, 131, 836848.

Kwon, H. B. \& Lee, J. (2019). Exploring the differential impact of environmental sustainability, operational efficiency, and corporate reputation on market valuation in high-tech-oriented firms. International Journal of Production Economics, 211, 1-14. 
Lee, S. Y. (2008). Drivers for the participation of small and medium-sized suppliers in green supply chain initiatives. Supply Chain Management: An International Journal, 13(3), 185-198.

Liu, Y., Quan B. T., Jeffrey Q. X., \& Forrest, Y. L. (2019). Corporate social responsibility and decision analysis in a supply chain through government subsidy. Journal of Cleaner Production, 208, 436-447.

Mustafa, S. A. (2016). The Importance of Corporate Social Responsibility on Company Performance Using the Partial Least Squares Approach. Asian Journal of Multidisciplinary Studies, 4(8), 128-134.

Narwal, M., \& Kant, R. (2014). Role of e-commerce in consumer decision making. International Journal of Research in Business Management, 2(6), 77-88.

Nunnally, J. C. (1978). Psychometric Theory. New York: McGraw-Hill.

Öberseder, M., Schlegelmilch, B. B., \& Gruber, V. (2011). "Why don't consumers care about CSR?": A qualitative study exploring the role of CSR in consumption decisions. Journal of Business Ethics, 104(4), 449-460.

Pang, X. N., Li, Z. J., Chen, J. Y., Gao, L. J., \& Han, B. Z. (2017). A Comprehensive Review of Spirit Drink Safety Standards and Regulations from an International Perspective. Journal of Food Protection, 80(3), 431-442.

Park, E. (2019). Corporate social responsibility as a determinant of corporate reputation in the airline industry. Journal of Retailing and Consumer Services, 47, 215-221.

Pomering, A. (2017). Communicating CSR Through Corporate Image Advertising. In Handbook of Integrated CSR Communication (pp. 171-190). Springer International Publishing.

Rahim, S. A., Mohammad, B., \& Rahman, N. A. A. (2016). Influencing Factors on Halal FourthParty Logistics (4PL) in Malaysia. In S. K. Ab Manan, F. A. Rahman, \& M. Sahri (Ed.), Contemporary Issues and Development in the Global Halal Industry (pp. 543-556). Springer Singapore.

Rahman, M., Rodríguez-Serrano, M. Á., \& Lambkin, M. (2017). Corporate Social Responsibility (CSR) and Marketing Performance: Role of Commitment to the Customer Relationship. In M. Stieler (Ed.), Creating Marketing Magic and Innovative Future Marketing Trends (pp. 667-671). Springer, Cham.

Ruslan, A. A. A., Kamarulzaman, N. H., \& Sanny, M. (2018). Muslim consumers' awareness and perception of Halal food fraud. International Food Research Journal, 25(1), 87- 96.

Rutsaert, P., Regan, Á., Pieniak, Z., McConnon, Á., Moss, A., Wall, P., \& Verbeke, W. (2013). The use of social media in food risk and benefit communication. Trends in Food Science \& Technology, 30(1), 84-91.

Sabki, S., Wong, W. C., \& Regupathi, A. (2019). SME Liquidity and Its Determinants. International Journal of Business and Society, 20(1),111-124.

Samuel, K. E., Goury, M. L., Gunasekaran, A., \& Spalanzani, A. (2011). Knowledge management in supply chain: An empirical study from France. The Journal of Strategic Information Systems, 20(3), 283-306.

Sancha, C., Gimenez, C., \& Sierra, V. (2016). Achieving a socially responsible supply chain through assessment and collaboration. Journal of Cleaner Production, 112, 1934-1947.

Sardianou, E., Stauropoulou, A., \& Kostakis, I. (2017). Analyzing Consumers' Awareness towards CSR, Focusing on Environmental Management. Environmental Management and Sustainable Development, 6(2), 51-64.

Schnittfeld, N. L., \& Busch, T. (2016). Sustainability management within supply chains-a resource dependence view. Business Strategy and the Environment, 25(5), 337-354. 
SME Corp. Malaysia. (2018). Small Medium Enterprise (SME) Annual Report 2017/18. http://www.smecorp.gov.my/images/SMEAR/SMEAR2017/ENG/FULL.pdf

Snider, A., Gutiérrez, I., Sibelet, N., \& Faure, G. (2017). Small farmer cooperatives and voluntary coffee certifications: Rewarding progressive farmers of engendering widespread change in Costa Rica?. Food Policy, 69, 231-242.

Song, M., Di Benedetto, A., \& Nason, R.W. (2007). Capabilities and financial performance: The moderating effect of strategic type. Journal of the Academy of Marketing Science, 35, 1834.

Soosay, C., Fearne, A., \& Dent, B. (2012). Sustainable value chain analysis-a case study of Oxford Landing from "vine to dine". Supply Chain Management: An International Journal, 17(1), 68-77.

Souza-Monteiro, D. \& Hooker, N. (2017). Comparing UK food retailers corporate social responsibility strategies. British Food Journal, 119(3), 658-675.

Torugsa, N. A., O’Donohue, W., \& Hecker, R. (2012). Capabilities, proactive CSR and financial performance in SMEs: Empirical evidence from an Australian manufacturing industry sector. Journal of business ethics, 109(4), 483-500.

Valdez-Juárez, L. E., Gallardo-Vázquez, D., \& Ramos-Escobar, E. A. (2018). CSR and the Supply Chain: Effects on the Results of SMEs. Sustainability, 10(7), 1-27.

Vorhies, D. W., \& Morgan, N. A. (2005). Benchmarking marketing capabilities for sustainable competitive advantage. Journal of Marketing, 69(1), 80-94.

Wei, W., Kimb, G., Miao, L., Behnke C., \& Almanza, B. (2018). Consumer inferences of corporate social responsibility (CSR) claims on packaged foods. Journal of Business Research, 83, 186-201.

Welford, R., \& Frost, S. (2006). Corporate social responsibility in Asian supply chains. Corporate Social Responsibility and Environmental Management, 13(3), 166-176.

Wetzels, M., Odekerken-Schroder, G., \& Van Oppen, C. (2009). Using PLS Path Modeling for Assessing Hierarchical Construct Models: Guidelines and Empirical Illustration, MIS Quarterly, 33(1), 177-195.

Xie, X., Zeng, S., Peng, Y., \& Tam, C. (2013). What affects the innovation performance of small and medium-sized enterprises in China? Innovation, 15(3), 271-286.

Yin, J., \& Zhang, Y. (2012). Institutional dynamics and corporate social responsibility (CSR) in an emerging country context: Evidence from China. Journal of Business Ethics, 111(2), 301-316.

Zhang, D., Gao, Y., \& Morse, S. (2015). Corporate social responsibility and food risk management in China; a management perspective. Food Control, 49, 2-10.

Zhao, M., Tan, J., \& Park, S. H. (2014). From voids to sophistication: Institutional environment and MNC CSR crisis in emerging markets. Journal of Business Ethics, 122(4), 655-674.

Zhu, Q., \& Lai, K. (2019). Enhancing supply chain operations with extended corporate social responsibility practices by multinational enterprises: Social capital perspective from Chinese suppliers. International Journal of Production Economics, 213, 1-12. 